\title{
MURINE (ENDEMIC) TYPHUS IN BRAZIL: CASE REPORT AND REVIEW
}

\author{
Luiz J. SILVA(1) \& Priscila M.O. PAPAIORDANOU ${ }^{\dagger}$
}

\begin{abstract}
SUMMARY
Murine typhus has been increasingly recognized worldwide and is becoming a relevant differential diagnosis in febrile conditions. In Brazil, murine typhus has never received much attention. We present a recently diagnosed case and a literature review that suggests that the disease could be more prevalent in Southeastern Brazil than acknowledged until now.
\end{abstract}

KEYWORDS: Murine typhus; Brazil; Rickettsial infections; Rickettsia typhi.

\section{INTRODUCTION}

Rickettsial diseases have enjoyed an upsurge of interest worldwide in recent years, with the recognition of their public health relevance and with the description of many new species.

Brazilian spotted fever, a tick-borne spotted-fever group disease caused by Rickettsia rickettsi, with considerable similarity to Rocky Mountain spotted fever, is by far the best known rickettsial disease in Brazil. Even so, it has only recently been included in the list of notifiable diseases. In addition, in a search in the Web site of the "Secretaria de Vigilância em Saúde" [http://dtr2001.saude.gov.br/svs], the national agency for disease control, one will find no mention of the disease, absent also from the handbook of infectious diseases control of the same agency ${ }^{9}$.

Murine typhus is known to occur in Brazil, but published reports are scarce, particularly in the last decades.

Murine, or endemic, typhus is caused by Rickettsia typhi, previously known as Rickettsia mooseri. It is classified as a typhus-group rickettsia, transmitted by fleas and has rodents as its main reservoirs. The occurrence seems to be worldwide ${ }^{2}$, and outbreaks have been described in all continents except Antarctica ${ }^{3}$.

Murine typhus is the only typhus-group rickettsial disease known to occur in Brazil, although the last published case-report dates from $1985^{13}$. Classic louse-borne typhus seems to have never occurred, but recurrent typhus (Brill's disease) was reported in the early 1950's, in a refugee from Eastern Europe ${ }^{8}$.

The authors describe a case of murine typhus acquired in southern Brazil (Ubiratã, Paraná) and review published reports of its occurrence in Brazil.

\section{CASE REPORT}

E.F.L., Caucasian, male, 35 year-old, born and living in Ubiratã (northwest of the southern Brazilian state of Paraná). The patient was a laborer in a local agricultural cooperative, where he performed various menial jobs in the grain warehouse (mostly maize and soybeans). $\mathrm{He}$ had an unremarkable previous medical history. He was admitted to the Hospital das Clínicas da Universidade Estadual de Campinas (a teaching general hospital and an acute regional referral center) in December 12th, 1998.

The patient gave a history of daily fever of approximately two weeks duration, predominantly in the afternoon, with chills and sweating, without other significant signs or symptoms. He was admitted to a local hospital in his hometown without a definite diagnosis and treated with ceftriaxone, $1 \mathrm{~g}$ qd IV, but his condition remained unchanged. Unsatisfied, he traveled to Campinas, in the neighboring state of São Paulo, where he had relatives, seeking a precise diagnosis and appropriate treatment.

At admission, the patient was in good clinical condition, febrile, attentive and responsive. He had a discrete maculo-papular exanthem, covering his entire body except face and a slight hepato- and splenomegaly. No other relevant findings.

A tentative diagnosis of murine typhus was made based on the history and clinical findings. His occupation called attention, particularly his admission that when his supervisor was away he took frequent naps lying on the grain sacks, and that there were numerous rodents in the warehouse.

The diagnosis was confirmed by a positive indirect immunofluorescent test, with antigens from the Centers for Disease Control,

\footnotetext{
(1) Faculdade de Ciências Médicas da Unicamp, Campinas, SP, Brazil and Superintendência do Controle de Endemias, Secretaria Estadual da Saúde, São Paulo, SP, Brazil.

${ }^{\dagger}$ Faculdade de Ciências Médicas da Unicamp, Campinas, SP, Brazil. In memoriam

Correspondence to: Luiz J. Silva, Sucen, R. Paula Sousa 166, 01027-000 São Paulo, SP, Brazil; fax: (55) 11-229-8292. E-mail: ljsilva@ sucen.sp.gov.br
} 
performed at the Instituto Adolfo Lutz (IAL, the State Public Health Laboratory of São Paulo). The test was positive at dilutions higher than $1 / 64$ for typhus-group rickettsial antigen and positive only below $1 / 32$ dilution for spotted-fever group antigen.

The patient was treated with doxycycline $100 \mathrm{mg}$ bid, p.o. for 14 days. His recovery was very good, becoming afebrile on the second day and was discharged after five days oftreatment. The patient was examined in two other occasions, three and four months after discharge, and was in good health.

An indirect immunoflurescent assay for leptospirosis was positive for Leptospira icterohemorrhagiae at a dilution of 1/400, but negative on two subsequent occasions, three and four months afterwards (March $3^{\text {rd }}$ and April 19 $\left.{ }^{\text {th }}, 1999\right)$, when antibody levels for typhus-group rickettsiae were persistently elevated.

Biochemical and hematological tests were unremarkable, except for a three-fold elevation of aspartate amino transferase and alanine amino transferase, that subsided to normal when discharged.

\section{MURINE TYPHUS IN BRAZIL}

The first published report of a confirmed case of murine typhus in Brazil was in 1948, in São Paulo ${ }^{15}$. Before that, murine typhus was suspected but not confirmed ${ }^{5,10}$. Some time after, Rickettsia mooseri [typhi] was isolated from rats in Rio de Janeiro ${ }^{11}$.

Brazilian spotted fever was identified in São Paulo in 1929, when an outbreak in the outskirts of the city called attention to a cluster of patients with a febrile exanthematous disease with a high case-fatality rate $(70 \%)^{4,12}$. The authors were able to isolate a small intracellular Gramnegative coco-bacillus that later they identified as a rickettsia, and similar to the Rocky Mountain spotted fever agent. This disease was initially named São Paulo typhus, "typho exanthematico de São Paulo", "typho exanthematico paulista", and later Brazilian spotted fever. In addition they were also able to isolate the bacteria from ticks (Amblyomma spp.) and small mammals. In the series of publications that followed their initial description of the outbreak, they also isolated rickettsiae from fleas, urban rats and described many cases occurring not in the outskirts of the city, but in the central areas, where no ticks or small mammals, other than rats, could be found. Many of the cases were mild, with a low case-fatality ${ }^{12}$.

As from then many researchers pointed out the existence of a benign form of spotted fever, usually associated with rats and their fleas, as in the article published in 1941 by GOMES, where he described four cases of a benign form of "typhus" in São Paulo 5 . Three of the patients worked as rat trappers for plague surveillance and the other worked in the warehouse district near the central market. Before that, in 1933, the IAL decided to test for rickettsia antibodies (Weil-Felix test) all samples sent in for typhoid testing (blood culture and Widal test). Many samples resulted positive for rickettsiae and negative for typhoid. Some of these patients had a benign clinical course with full recovery, sometimes without rash. What seemed as a variant form of spotted fever could have been in fact murine typhus. The same observation was made by researchers in Minas Gerais, where benign cases occurred among more severe cases, suggesting that at least some of these were murine typhus ${ }^{6,7}$.
In 1954, ANADÃO ${ }^{1}$ reports that murine typhus was endemic in São Sebastião da Grama, a small rural town in the State of São Paulo, located in a hilly area north of the capital, São Paulo. He gives a brief description of 70 cases, diagnosed clinically and serologically (Weil-Felix) but none were culture-confirmed. The rather mild manifestations, with no deaths, and the abundant presence of rats and fleas mostly in barns, stables and warehouses with maize and potatoes, and also the apparent disappearance of the disease after an energetic rat and flea control campaign all speak in favor of the author's diagnosis. This is the only report we could find describing an outbreak of murine typhus in Brazil.

It is reasonable to hypothesize that if murine typhus was not uncommon in rural areas in the State of São Paulo, the intensive malaria and later Chagas disease eradication campaigns conducted for almost 30 years, from the early 1950's up to 1980, could have had an impact on the rat-flea population and consequently in the number of murine typhus occurrences. The malaria campaign used enormous amounts of DDT, and the Chagas disease campaign used BHC, also in massive amounts. Both are organo-chloride insecticides, highly effective against fleas, and with a residual capacity lasting for months. The Chagas disease eradication campaign sprayed not only human dwellings but also chicken coops and deposits, stables and warehouses, known to harbor the reduvid vectors of Chagas disease.

No other paper from 1985 to date was found in a search of Medline (1966-2003) and Oldmedline (1953-1965) using murine typhus AND Brazil; typhus AND Brazil; rickettsia AND Brazil. A manual search of the Tropical Medicine Bulletin from 1908 to 2003 and an on-line search of Lilacs [http://www.bireme.br/bvs/I/ihome.htm], the Medline-style Latin American and Caribean health literature data-base also yielded no papers apart from those mentioned.

A retrospective analysis of patients admitted to Hospital Emilio Ribas, the Public Health Service isolation hospital in São Paulo, suggests that apparently murine typhus, spotted fever and recurrent typhus (Brill's disease) occurred in São Paulo at least since 1904, based on autopsy reports and patient's records ${ }^{14}$. The authors diagnosed one other case, acquired in Campinas, SP (southeastern Brazil) in 1980, in a patient that worked in a warehouse for animal feed, confirmed with indirect immunofluorescent assay, but not by culture. This case was not published.

There is sufficient evidence to indicate that murine typhus occurs in Brazil, with autochthonous transmission. Despite the lack of enough data to infer its distribution and incidence, this disease might not be uncommon. Rodents and their fleas are abundant in Brazil as elsewhere, so it seems that a more aggressive pursue of the diagnosis would uncover other cases.

The occurrence of cases from places fairly distant form each other, such as Ubiratã in Paraná, Campinas in São Paulo and Belo Horizonte in Minas Gerais indicates that murine typhus is widespread, at least in South and Southeastern Brazil, but under recognized and consequently under reported. The growing incidence of dengue in most of the urban areas of the country no doubt contributes to the difficulty in diagnosing murine typhus, as many cases could possibly be dismissed as dengue. The laboratory tests for diagnosis are mostly unavailable, contributing for the low perception of the disease in Brazil. 


\section{RESUMO}

\section{Tifo murino (endêmico) no Brasil: relato de caso e revisão}

O tifo murino tem sido reconhecido com frequiência crescente em todo o mundo e vem se tornando um relevante diagnóstico diferencial de quadros febris. No Brasill, o tifo murino nunca mereceu grande atenção. Descrevemos um caso clínico e fazemos revisão da literatura que sugere que a doença poderia ser mais prevalente no sudeste brasileiro do que reconhecido até então.

\section{REFERENCES}

1. ANADÃO, A. - A alta incidência do tifo murino no município de São Sebastião da Grama (São Paulo). Rev. paul. Med., 44: 431, 1954

2. AZAD, A.F. - Epidemiology of murine typhus. Ann. Rev. Entomol., 35: 553-569, 1990.

3. AZAD, A.F. \& BEARD, C.B. - Rickettsial pathogens and their arthropod vectors. Emerg. infect. Dis., 4: 179-186, 1998.

4. DIAS, E. \& MARTINS, A.V. - Spotted fever in Brazil: a summary. Amer. J. trop. Med. Hyg., 19: 103-108, 1939.

5. GOMES, L.S. - Sobre a presença do tifo exantemático do tipo murino ou endêmico em São Paulo. Estudo de quatro casos prováveis. Rev. Inst. Adolfo Lutz, 1(1): 21-39, 1941

6. MAGALHÃES, O. \& MOREIRA, J.A. - Typho exanthematico em Minas Gerais. Brasilméd., 53: 882-891, 1939.
7. MAGAlHÃES, O. \& ROCHA, A. - Tifo exanthematico do Brasil (em Minas Gerais) Brasil-méd., 55: 773-777, 1941.

8. MEIRA, J.A.; JAMRA, M. \& LODOVICI, J. - Moléstia de Brill (recrudescência do tifo epidêmico). Rev. Hosp. Clin. Fac. Med. S. Paulo, 10: 237-246, 1955.

9. MINISTÉRIO DA SAÚDE/FUNDAÇÃO NACIONAL DE SAÚDE/CENTRO NACIONAL DE EPIDEMIOLOGIA - Doenças infecciosas e parasitárias. Aspectos clínicos, vigilância epidemiológica e medidas de controle. Brasília, Ministério da Saúde/Fundação Nacional de Saúde, 1999.

10. MONTEIRO, J.L. \& FONSECA, F. - Typho exanthematico de S. Paulo. XII. Sobre um "virus" isolado de ratos da zona urbana da cidade e de suas relações com o do typho exanthematico de S. Paulo. Brasil-méd., 46: 1029-1033, 1932

11. PEREIRA, H.G.; TRAVASSOS, J. \& VASCONCELOS, J.V. - Tifo murino no Rio de Janeiro. I. Ocorrência de ratos naturalmente infectados. Hospital (Rio de J.), 35: 679-687, 1949.

12. PIZA, J.T.; MEYER, J.R. \& GOMES, L.S. - Typho exanthematico de São Paulo. São Paulo, Sociedade Impressora Paulista, 1932

13. SILVEIRA, J.C.B. \& MAESTRINI, A.A. - Tifo murino: a propósito de um caso. An Fac. Med. Univ. Fed. Minas Gerais, 34: 103-106, 1985.

14. TIRIBA, A.C. - Geografia médica das riquetsioses. In: LACAZ, C.S.; BARUZZI, R.G. \& SIQUEIRA Jr., W., ed. Introdução à Geografia médica do Brasil. São Paulo, Edgard Blücher/Edusp, 1972. p. 388-397

15. TRAVASSOS, J.; RODRIGUES, P.M. \& CARRIJO, L.N. - Tifo murino em São Paulo Identificação da Rickettsia mooseri isolada de um caso humano. Mem. Inst. Butantã, 21: 77-106, 1949.

Received: 9 June 2004

Accepted: 24 August 2004 